\title{
Article
}

\section{Is the Threat of Foreign Aid Withdrawal an Effective Deterrent to Political Oppression? Evidence from 53 African Countries}

\author{
Asongu, Simplice and Nwachukwu, Jacinta Chikaodi
}

Available at http://clok.uclan.ac.uk/25145/

Asongu, Simplice and Nwachukwu, Jacinta Chikaodi ORCID: 0000-0003-29879242 (2017) Is the Threat of Foreign Aid Withdrawal an Effective Deterrent to Political Oppression? Evidence from 53 African Countries. Journal of Economic Issues, 51 (1). pp. 201-221. ISSN 0021-3624

It is advisable to refer to the publisher's version if you intend to cite from the work. http://dx.doi.org/10.1080/00213624.2017.1287510

For more information about UCLan's research in this area go to http://www.uclan.ac.uk/researchgroups/ and search for <name of research Group>.

For information about Research generally at UCLan please go to http://www.uclan.ac.uk/research/

All outputs in CLoK are protected by Intellectual Property Rights law, including Copyright law. Copyright, IPR and Moral Rights for the works on this site are retained by the individual authors and/or other copyright owners. Terms and conditions for use of this material are defined in the policies page. 


\section{MPRA \\ Munich Personal RePEc Archive}

\section{Is the Threat of Foreign Aid Withdrawal an Effective Deterrent to Political Oppression? Evidence from 53 African Countries}

Simplice Asongu and Jacinta Nwachukwu

January 2016

Online at https://mpra.ub.uni-muenchen.de/74649/

MPRA Paper No. 74649, posted 19 October 2016 03:05 UTC 


\title{
$\underline{\text { A G D I Working Paper }}$
}

\section{$\mathrm{WP} / 16 / 020$}

\section{Is the Threat of Foreign Aid Withdrawal an Effective Deterrent to Political Oppression? Evidence from 53 African Countries}

Forthcoming: Journal of Economic Issues

\author{
Simplice A. Asongu \\ African Governance and Development Institute, \\ P.O. Box 8413 Yaoundé, Cameroon. \\ E-mail: asongusimplice@yahoo.com /asongus@afridev.org
}

Jacinta C. Nwachukwu

School of Economics, Finance and Accounting,

Faculty of Business and Law, Coventry University

Priory Street, Coventry, CV1 5FB, UK

Email: jacinta.nwachukwu@coventry.ac.uk 


\title{
AGDI Working Paper
}

\author{
Research Department
}

\section{Is the Threat of Foreign Aid Withdrawal an Effective Deterrent to Political Oppression? Evidence from 53 African Countries}

\section{Simplice A. Asongu \& Jacinta C. Nwachukwu}

January 2016

\begin{abstract}
This study complements existing literature on the aid-institutions nexus by focusing on political rights, aid volatilities and the post-Berlin Wall period. The findings show that while foreign aid does not have a significant effect on political rights, foreign aid volatilities do mitigate democracy in recipient countries. Such volatilities could be used by populist parties to promote a neocolonial agenda, instill nationalistic sentiments and consolidate their grip on power. This is especially the case when donors are asking for standards that majority of the population do not want and political leaders are unwilling to implement them. The empirical evidence is based on 53 African countries for the period 1996-2010. As a main policy implication, creating uncertainties in foreign aid for political rights enhancement in African countries may achieve the opposite results. Other implications are discussed including the need for an 'After Washington consensus'.

JEL Classification: C53; F35; F47; O11; O55

Keywords: Uncertainty; Foreign aid; Political Rights; Development; Africa
\end{abstract}




\section{Introduction}

The need for genuine democracy in Africa is now a subject of substantial consensus (Wantchekon, 2003; Vicente \& Wantchekon, 2009). The use of foreign aid as a policy instrument for the promotion of political rights in recipient countries after the fall of the Berlin Wall is also a widely accepted fact in policy making and academic circles (Gibson et al., 2014; Killick, 2003; Crawford, 2001; Carothers, 2000; Stokke, 2013; Hayman, 2011; Faust, 2010). There has also been a recent stream of studies consistent with celebrated aid literatures ('The Bottom Billion' (Collier, 2007), 'Dead Aid' (Moyo, 2009)) in putting to question the effectiveness of development assistance as a policy instrument (Krause, 2013; Banuri, 2013; Marglin, 2013; Wamboye et al., 2013; Ghosh, 2013; Monni \& Spaventa, 2013; Titumir \& Kamal, 2013). According to the narrative, the possibility of neocolonialism increasingly governing foreign aid has been advocated by Amin (2013). A position earlier shared by Kindiki (2011) on the necessity for African countries to strategically overcome dependence on international regimes/systems and Ndlovu-Gatsheni (2013) on the entrapment of the continent within the matrices of colonial power. Obeng-Odoom (2013) has joined the chorus in asserting that aid policies should be complete process that clearly articulate the needs of African countries. This converges with Amin's position that development models should not be limited to donor thoughts on what is good for the continent.

The policy of making foreign aid uncertain by donors to influence politics in recipient countries is the very essence of the political economy of foreign aid. In fact, foreign aid as an instrument of regime change and the strengthening of democratic political values has prominently featured in Zimbabwe, post Arab Spring conflicts and recently in the adverse criminalization of gays in Uganda. In other words, aid supply is substantially contingent on the willingness of recipient nations to comply with conditions and motivations of donor countries. Donors are 
increasingly asking for higher standards of governance in exchange for their money. This is true, at least in theory of the Washington Consensus (WC) ${ }^{1}$ that prioritizes political rights over economic rights. In essence, consistent with Moyo (2013), the WC can be defined in three phrases: liberal democracy, private capitalism and priority in political rights. In the same vein after the fall of the Berlin Wall foreign aid became an instrument for the promotion of political rights (Gibson et al., 2014).

The interesting literature on foreign aid and institutions has centered around three main areas: the effect of foreign aid on institutional quality; whether donors grant more aid to countries with higher institutional standards and how aid can be used to improve institutional quality in recipient countries (Easterly, 2005). In line with the discourse, since poverty in African countries is substantially traceable to institutional bad quality, developed countries have to promote credible institutions in the continent (Knack, 2001; Dixit, 2004; Amavilah, 1998; Alesina \& Dollar, 2000; Alesina \& Weder, 2002; Armah \& Carl, 2008; Asongu, 2012a, 2013a; Jellal \& Bouzahzah, 2012; Asongu \& Jellal, 2013; Djankov et al., 2008). As highlighted in the first paragraph above, foreign aid volatility may be used by donor countries for this purpose. This paper focuses on the third strand of the aid-institutions literature and aims to assess whether such uncertainties in foreign aid flows are means by which political rights could be promoted in African countries. The contribution of the inquiry is original in improving scholarly understanding of the aid-institutions debate in the light of the case Somaliland which does not receive official foreign aid. The corresponding research question is as follows: is the threat of foreign aid withdrawal an effective deterrent to political oppression? The question is addressed

\footnotetext{
${ }^{1}$ In line with Marangos (2009), while the Washington Consensus has 'different versions and interpretations', the definition employed in this study is with respect to Moyo (2013). According to the author while the Washington Consensus can be defined as 'private capitalism, liberal democracy \& priority in political rights', the Beijing Consensus is summarized as 'state capitalism, de-emphasized democracy \& priority in economic rights'.
} 
by employing the Generalised Method of Moments on a sample of 53 African countries for the period 1996-2010.

While there has been a substantial literature on the aid-institution nexus, as far as we have reviewed, very few studies have focused on the aid-democracy relationship. The existing literature entails: general discourses or literature reviews (Brown, 2005), positive effects of aid on democratization (Knack, 2004), Kangoye (2011) using the same title as Knack to conclude that aid mitigates the negative impact of external shocks (terms of trade distortions) on democracy and Kano \& Montinola (2009) conclude that aid helps autocrats (democrats) more in the long-run (short-term). The present study steers clear of the above literature from two standpoints. First, it is focused on the period after the fall of the Berlin wall, essentially because the collapse of the wall was followed by a substantial change in aid-democracy policies (Gibson et al., 2014) ${ }^{2}$. Accordingly: Knack (2004) has used the period 1975-2000; Kangoye (2011), 1980-2003; Kano \& Montinola (2009), 1960-1999; Kalyvitis \& Vlachaki (2008), 1972-2004. Second, in light of stylized facts and recent developments in the aid debate, we focus on aid uncertainty.

The study is organized as follows. Section 2 briefly summarizes the state of the debate on the aid-democracy nexus. Data and methodology are discussed in Section 3. The empirical analysis and discussion of results are covered in Section 4. We conclude with Section 5.

\section{Foreign aid, institutions and democracy: connecting the dots of recent debates}

The study extends ongoing debates in the aid-institutions literature: one old and two recent. The first is the old strand, the level and time hypotheses for democratic benefits (Scott, 1972; Lemarchand, 1972; Sayari, 1977; Varsee, 1997; Wade, 1985; Weyland, 1998; Sung, 2004; Back

\footnotetext{
2 "The roots of the Washington consensus that grew in the 1980s and the end of the Cold War quickly changed this status quo: in addition to strong external pressure to liberalize, rulers began to face increasing constraints to using foreign aid to support their followers. While aid continued to flow, it came increasingly in forms far less amenable to patronage politics". (p. 25)
} 
\& Hadenius, 2008; Montinola \& Jackman, 2002; Asongu, 2011; Asongu, 2012b). Second, China's spectacular growth has led to a growing stream of debates on the priority of political rights (Washington Consensus) over economic rights (Beijing Consensus) in development models (Moyo, 2013; Ortmann, 2012; Lalountas et al., 2011; Asongu \& Aminkeng, 2013; Asongu, 2014a; Anyanwu \& Erhijakpor, 2014). Hence, the study improves on the Beijing Model and Washington Consensus debate in a twofold manner: (1) the Moyo's (2013) conjecture on political versus economic rights and (2) the hypothesis that at the advent of globalization, poor countries are more concerned with economic rights in comparison to political rights (Lalountas et al., 2011; Asongu, 2014a). Third, debates on the aid-institutions nexus, amongst others: the aidcorruption relationship (Okada \& Samreth, 2012; Asongu \& Jellal, 2013; Asongu, 2012a, 2013a), verification of the celebrated Eubank $(2012)^{3}$ literature (Asongu, 2015) and usage of the Eubank conjecture to extend some findings in the aid-governance literature (Kangoye, 2013 versus Asongu, 2014b).

We further discuss this section in two main strands: debates surrounding the aidinstitutions nexus and the aid-democracy relationship. The former is presented in three main streams: the time and level hypotheses for the benefits of institutional quality, the Washington consensus versus the Chinese model on priority of economic rights versus political rights in the scale of rights preferences and a recent wave of debates on aid and institutions.

The first stream focuses on the level and time hypotheses of institutional quality rewards. In essence, developing nations need to mature (time) and be strong (level) to fully reap the rewards of democratic institutions. With regards to the level of institutions hypothesis, it has been confirmed with the help of continuous governance measurements that institutional quality is highest in strongly democratic nations, medium in strongly authoritarian countries and least in

\footnotetext{
${ }^{3}$ Eubank (2012) received the best paper Award in 2013 from the Journal of Development Studies.
} 
partially democratic countries. Employing different empirical specifications, non-linearity in the level hypothesis has been established as: J-shaped (Back \& Hadenius, 2008); S-shaped (Sung, 2004) or U-shaped (Montinola \& Jackman, 2002). Asongu (2011) has verified this hypothesis in Africa by concluding that young or partial democratic countries perform worst (worse) relative to older or quasi-full democracies (autocracies). Regarding the time of exposure hypothesis, it has been established by Keefer (2007) that young (old) democracies have lower (higher) institutional quality. In accordance with Asongu (2012b), the level and time hypotheses have been reported in empirical and theoretical studies: Southeast Asia (Scott, 1972), Turkey (Sayari, 1977), India (Wade, 1985), post 1990 nations like Russia (Varsee, 1997), a considerable number of Latin American nations after the streams of democratization processes (Weyland, 1998) and, African nations (Lemarchand, 1972).

The second strand of studies involve the debate between the Beijing Consensus (BC) and Washington Consensus (WC) on the priority of economic over political rights in models of development (Carmody \& Owusu, 2007; Anyanwu \& Erhijakpor, 2014; Asongu \& Aminkeng, 2013; Lalountas et al., 2011; Ortmann, 2012; Asongu, 2014a; Moyo, 2013). The debate has been heightened by China's breath-taking tale of economic transformation. The success of the country has raised concerns over the orthodoxy of institutions preceding economic prosperity in the development process (Wang \& Zheng, 2012; Tull, 2006). There is a thesis by the WC which postulates that economic rights should follow political rights (Clinton, 2011). On the other hand, an antithesis from the $\mathrm{BC}$ sustains that political rights should come after economic rights (Akomolafe, 2008; Ortmann, 2012). A third school of thought (or synthesis) has reconciled these two axes with a position that both the $\mathrm{BC}$ and $\mathrm{WC}$ are needed in the short-term and long-run respectively (Lalountas et al., 2011; Moyo, 2013; Asongu, 2014a). According to this third narrative (also known as the Moyo hypothesis (Asongu, 2015)), for the WC to sustainably 
prioritize political rights, a middle-class is needed to demand them genuinely. The core argument is that the $\mathrm{BC}$ is the model that can deliver the middle-class within the shortest spell of time. The synthesis further sustains that the WC should be the preferable long-term development strategy because it is a more inclusive model. The $\mathrm{BC}$ versus $\mathrm{WC}$ debate has also initiated a growing stream of studies on multi-polar development strategies (Wa Gĩthĩnji \& Adesida, 2011; Babatunde, 2012; Fosu, 2010, 2012, 2013a; Nyarko, 2013a) ${ }^{4}$.

We briefly discuss some recent waves of debates on foreign aid and institutional quality. First, the Okada \& Samreth (2012) and Asongu (2012a, 2013a) discussion on the 'effect of foreign aid on corruption' has been reconciled by Asongu \& Jellal (2013) using fiscal behavior channels. They have concluded that the impact depends on the transmission mechanisms of aid, among others, through government spending (tax effort or private investment) improves (mitigates) corruption. In this debate, Asongu (2012a) could not verify the Okada \& Samreth results on the negative aid-corruption relationship in Africa. He has further confirmed his position using the methodological framework of Okada \& Samreth in Asongu (2013a). The textual literature of the celebrated Eubank (2012) literature on the negative incidence of aid on political governance has been empirically verified by Asongu (2015) using a taxation mechanism. In clarifying Kangoye (2013), Asongu (2014b) has further used the Eubank conjecture. Accordingly, he has established that the Kangoye findings are irrelevant (relevant) for Africa when the concept of governance is extended (restricted) to more concepts of government (corruption).

\footnotetext{
${ }^{4}$ Recently, Fosu (2013a) has documented an interesting strand of literature on multi-polar strategies of development. They include, inter alia, lessons from: Latin America \& the Caribbean (Trejos, 2013; De Mello, 2013; Solimano, 2013; Pozo et al., 2013; Cardoso, 2013); East Asia \& the Pacific (Warr, 2013; Thoburn, 2013; Lee, 2013; Jomo \& Wee, 2013; Khan, 2013); the emerging Asian giants of China \& India (Singh, 2013; Yao, 2013; Santos-Paulino, 2013); the Middle East \& North Africa (Baliamoune-Lutz, 2013; Looney, 2013; Drine, 2013; Nyarko, 2013b) and; sub-Saharan Africa (Fosu, 2013b; Subramanian, 2013; Robinson, 2013; Lundahl \& Petersson, 2013; Naudé, 2013).
} 
While there has been a substantial literature on the aid-institution nexus, as far as we have reviewed, very few studies have focused on the aid-democracy relationship. We discuss the literature in terms of literature review (Brown, 2005) as well as positive (Knack, 2004; Kangoye, 2011) and mixed (positive and negative) effects (Kano \& Montinola, 2009; Kalyvitis \& Vlachaki 2008) of foreign aid on democracy.

Brown (2005) has essentially focused on a review of the literature based on the disappointing results of international efforts of democratization that are for the most part attributed to domestic conditions which substantially hamper the establishment and survival of democracy. The study acknowledges substantial structural setbacks exist and that the democratization process is mainly due to an endogenous scenario or domestic factors. It further argues that international actors who are most often absent from mainstream democratization theories could however play a major role in the prevention (or promotion) of democratization processes in sub-Saharan Africa (SSA). Unfortunately, the mission of donors in the promotion of quick transition to multiparty systems of democracy could hold-back the democratization process.

On the positive effects, Knack (2004) has concluded that aid potentially contributed to processes of democratization in many ways, inter alia: (1) via technical assistance that targets electoral processes, promotes civil society organizations like freedom of the press, consolidates the legislatures and judiciaries and (2) improvements in education and income which are ideal for democratization and via conditionality. Kangoye (2011), using the same title as Knack (2004) has established that aid could mitigate the negative effects of terms of trade volatility on democracy. Kano \& Montinola (2009) concluded that aid helps autocrats (democrats) more in the long-run (short-term); there is strong evidence supporting the positive association between 
democratic aid flows and the possibility of observing fully- or partly-democratic political regimes (Kalyvitis \& Vlachaki, 2008).

The present study steers clear of the above literature from two standpoints. First, it is focused on the period after the fall of the Berlin wall, since the collapse of the wall was followed by a substantial change in aid-democracy policies (Gibson et al., 2014). Accordingly: Knack (2004) has used data for the period 1975-2000; Kangoye (2011), 1980-2003; Kano \& Montinola (2009), 1960-1999; Kalyvitis \& Vlachaki (2008), 1972-2004. Second, in light of stylized facts and recent developments in the aid debates, we focus on aid uncertainty.

\section{Data and Methodology}

\subsection{Data}

We assess a panel of 53 African nations with annual data from World Bank Development Indicators for the period 1996-2010. The periodicity has a twofold justification. First, as documented above, it enables us to capture how aid volatilities have affected political rights after the fall of the Berlin wall. Second, for comparative purposes, the same periodicity has been employed by most of the underlying studies discussed in the debate strands on 'aid and institutions' of the literature section also above (for example the Okada, Samreth, Asongu \& Jellal debate $)^{5}$.

The dependent variables are institutionalized autocracies and democracies. Net official development assistance (NODA) is the principal independent variable to which we add NODA from the Development Assistance Committee (DAC) countries for robustness purposes. Consistent with Asongu (2014c), foreign aid volatilities are computed in a twofold manner: (1) standard errors or standard deviations of the saved residuals after first-order autoregressive

\footnotetext{
5 Accordingly, Okada \& Samreth (2012), Asongu (2012a), Asongu (2013a) and Asongu \& Jellal (2013) have respectively used data for the period '1995-2009', '1996-2010', '1996-2010' and '1996-2010'.
} 
processes of the NODA indicators and (2) simple standard deviations of three-year intervals. The former approach is in line with Kangoye (2013).

There is a fourfold justification for the choice of three-year averages in terms of nonoverlapping intervals (NOI). First, there is a one degree of freedom loss when the residuals are computed with first-order autoregressive processes. Moreover, a minimum of two periods are required to compute the standard deviations of corresponding residuals. Second, using data averages enables the mitigation of short-term disturbances. Third, with three year NOI, the basic conditions for the use of Generalized Methods of Moments (GMM) are fulfilled (N>T: 53>5). Fourth, data averages restrict overidentification or limit the proliferation of instruments by ensuring that the instruments are lower than the number of cross-sections in every specification.

Consistent with Asongu (2014c), in the regressions, we control for economic prosperity in terms of GDP growth, trade openness, government expenditure and inflation. The expected sign of government expenditure is ambiguous at best. It could be positive (negative) on political rights if the funds are from taxation (foreign aid). The tax effort and aid channels are consistent with Eubank (2012) and Asongu \& Jellal (2013) respectively. Globalization reflected in trade openness has been documented to improve governance standards (Khandelwal \& Roitman, 2012), though more in high income countries (Lalountas et al., 2011; Asongu, 2014a). Economic prosperity with respect to income-levels has also been documented to be instrumental in improving government quality (Asongu, 2012, p. 191). The expected sign from inflation to political rights is also ambiguous. Accordingly, it could be appealing if adopted measures in response to consumer price inflation are designed to improve on government quality and mitigate soaring prices. Alternatively, it could also seriously affect social order when the issues are not timely tackled. The latter postulation is consistent with the documented causes of the Arab Spring 
(Khandelwal \& Roitman, 2012; Asongu, 2015). In the GMM specifications, time-effects are also employed to control for the unobserved heterogeneity.

The variables are defined in Appendix 1, the summary statistics reported in Appendix 2, while Appendix 3 presents the correlation matrix. The latest is employed to mitigate potential issues of multicollinearity and overparameterization in the NODA variables and their corresponding distortions. From the variations observed in Appendix 2, we can be confident that reasonable estimated nexuses would emerge.

\subsection{Methodology}

Consistent with Asongu (2013b), a dynamic panel GMM estimation approach is adopted for three principal reasons: first, it has some bite on endogeneity as it controls for time invariant omitted variables, second, it does not eliminate cross-country regressions and third, it corrects small sample bias issues from difference estimators. Therefore, this third advantage is the main criterion that has guided our preference for system GMM (Arellano \& Bover, 1995; Blundell \& Bond, 1998; Bond et al., 2001, pp. 3-4) in relation to a difference GMM estimator (Arellano \& Bond, 1991). A heteroscedasticity-consistent two-step method is used instead of the one-step procedure which is homoscedasticity-consistent. Two main tests are performed to assess the validity of the models, notably: the over-identifying restrictions (OIR) Sargan test for the validity of instruments and; the Arellano \& Bond autocorrelation (AR(2)) test for the absence of autocorrelation in the residuals. The interests of using data averages in terms of 3 year NOI have already been discussed in the data section.

The following equations in levels (Eq. 1) and first difference (Eq. 2) represent the GMM approach. 


$$
\begin{aligned}
& P R_{i, t}=\sigma_{0}+\sigma_{1} \text { Gov }_{i, t-1}+\sigma_{2} T_{i, t}+\sigma_{3} D A C_{i, t}+\sum_{j=1}^{4} \partial_{j} X_{i, t}+\eta_{i}+\xi_{t}+\varepsilon_{i, t} \\
& P R_{i, t}-P R_{i, t-1}=\sigma_{1}\left(P R_{i, t-1}-P R_{i, t-2}\right)+\sigma_{2}\left(T_{i, t}-T_{i, t-1}\right)+\sigma_{3}\left(D A C_{i, t}-D A C_{i, t-1}\right) \\
& +\sum_{j=1}^{4} \partial_{j}\left(X_{i, t}-X_{i, t-1}\right)+\left(\xi_{t}-\xi_{t-1}\right)+\left(\varepsilon_{i, t}-\varepsilon_{i, t-1}\right)
\end{aligned}
$$

Where: 't' denotes the period and ' $i$ ' stands for a country. $P R$ represents political rights in terms of democracy or autocracy; $T$, Total NODA; DAC, NODA from DAC countries; $X$ is the set of control variables (Government expenditure, Trade openness, GDP growth, and Inflation); $\xi_{t}$ is a time-specific constant; $\eta_{i}$ is a country-specific effect and; $\varepsilon_{i, t}$ an error term. The estimation procedure involves jointly estimating the equation in level with that in first-difference, therefore exploiting all the orthogonality or parallel conditions between the lagged endogenous variable and the error term.

\section{Empirical results}

The section addresses two main issues: the effect of foreign aid on political rights and the impact of aid distortions or uncertainty on political rights. We have taken a minimalist approach by assuming that foreign aid volatilities exclusively are determined by the interest of donor nations to foster political rights in African countries. In other words, it could be said that the distribution of foreign aid is essentially based on the degree of political governance in a given country. This assumption appears somewhat plausible in light of the case of Zimbabwe (discussed in Section 4.3.1).

While Section 1 is based on aid volatilities measured as simple standard deviations (Table 1), in Section 2, foreign aid uncertainty is appreciated as the standard deviations of residuals after first-order autoregressive processes in the NODA variables (Table 2). Based on the information 
criteria for the validity of models, the null hypothesis of the OIR Sargan and AR(2) are not overwhelmingly rejected ${ }^{6}$.

\subsection{Distortions as standard deviations}

Table 1 below uses basic standard deviations as volatilities. While Table A contains specifications with total NODA, Table B reflects those with NODA from DAC countries. Two main findings are established: the effect of foreign aid on political rights is insignificant while the impact of foreign aid volatilities on democracy is negative. The significant control variable has the expected sign: inflation could substantially affect democratic processes.

"Insert Table 1 here"

\subsection{Robustness checks with volatilities as standard errors}

In Table 2 below, the specifications of Table 1 are replicated with total NODA (Panel A) and NODA from DAC countries (Panel B) for robustness purposes. The results are consistent with those of Table 1 above. Hence, while the effect of aid on political rights is not significant, that of volatilities on democracy is negative. The significant control variable also has the expected sign.

"Insert Table 2 here"

\footnotetext{
${ }^{6}$ In essence, we have performed two tests in order to assess the validity of the models, notably: the Arellano \& Bond autocorrelation test that examines the null hypothesis of no autocorrelation and the Sargan-test which examines overidentification restrictions. The latter test assesses whether the instruments are uncorrelated with the error term in the main equation. Overwhelmingly for all the models, we have neither been able to reject the AR(2) null hypothesis for the absence of autocorrelation nor the Sargan null for instrument validity.
} 


\subsection{Discussion of results and policy implications}

\subsubsection{Discussion of results}

The findings are broadly consistent with the literature on aid conditionality for political objectives in recipient countries (Killick, 2003; Crawford, 2001; Carothers, 2000; Stokke, 2013; Hayman, 2011; Faust, 2010). It is widely believed that foreign aid as a policy instrument for the promotion of political rights in recipient countries could be manipulated by donors to achieve the objective of enhancing democracy. This has been the case of Zimbabwe in recent years where aid manipulations for regime change only further consolidated power by the ZANU PF party. This shows how foreign aid uncertainty could be used by populist parties to promote a Western neocolonial agenda, instill nationalistic sentiments and consolidate their grip on power. Accordingly, since foreign aid benefits even those of the opposition political parties, in the longterm they too could start dancing to these populist tunes. A recent (early 2014) example is Uganda where an anti-gay bill voted by the legislature and signed into law by president Youweri Museveni has been greeted with a suspension of aid/loans by some donor countries, including multinational institutions like the World Bank. This is against the background that majority of Ugandans approve of such a bill.

In a nutshell, making foreign aid uncertain as a policy instrument to promote political rights in poor countries could instead become a political instrument to prolong stay in power. This is especially true if the 'foreign aid dictated measure' is unpopular and 'recipient country leadership' is unwilling to comply with the dictated measure because it is unpopular. Moreover, this sends a strong signal that African governments are constrained to be accountable to donors instead of any electorate that put them into office. This scenario contradicts the very essence of 
political accountability. In essence, democracy that is locally-oriented and consolidates feedbacks from citizens is a more appealing instrument for political governance than outside pressure.

In fact it is important to understand why the findings are they way they are. Accordingly, the political economy perspective of foreign aid is crucial in grasping these findings since the ambitions underlying aid are cocktails of culture, institutions, power distribution and dynamics of competitive interests (Schraeder et al., 1998; Hopkins, 2000). In other words, foreign aid is the product of bargaining of some nature in the political market that involves recipient governments, donor aid bureaucracies and multilateral assistance agencies. Essentially, different goals have motivated donors over time. Whereas Japanese and Chinese aid is motivated predominantly by economic gains, French assistance and Nordic aid are guided by politico-economic gains and global welfare improvement respectively.

With some exceptions of the emerging economies of East Asia, more concessions are increasingly being offered by African recipient nations to donor preferences in exchange for more aid. But most of these concessions are positively sanctioned by the electorate. One might even be tempted to establish that the strength with which foreign aid pressures was resisted by Egypt in the 1960s is not yet over. Accordingly, despite the threat of foreign aid uncertainties which represent a significant percentage of Egyptian budget and military expenditure, the definition of democracy has been revisited and redefined on several occasions over the past months in the country. Indeed there is a wide perception that the revolution was partly foreign-funded. While the manner in which this perception has affected the mechanics by which Morsi was ousted and a former military officer has become president with less than $50 \%$ of the population going to polls is unknown. An interesting lesson drawn from this experience is articulately summarized by Elagati (2013, p. 18): “Changing Egyptians' mindset about foreign funding is part of the task of moving from an authoritarian culture to a democratic one that understands and values the 
positive role played by civil society, political parties and the media. In order to change this mindset, fears of foreign funding need to be slowly deconstructed via a transparent public debate".

The above explanation goes a long way to establishing that, whereas African countries have today been substantially transformed into supplicants that come-up with a good number of projects in the hope that more aid would be granted (Lancaster, 1999; Hopkins, 2000), public perception may have the last say on who stays in power whether by real or crony democratic means. It is broadly in accordance with a recent stream of aid literature that has requested the imperative for a more thorough approach to development assistance: one that clearly articulates the needs and wants of citizens in recipients countries (Monni \& Spaventa, 2013; Krause, 2013; Marglin, 2013; Wamboye et al., 2013; Titumir \& Kamal, 2013; Banuri, 2013; Ghosh, 2013). In essence, the ramifications could be unappealing for donor image if aid distortions are not consistent with the demands of the electorate ${ }^{7}$. Kindiki (2011) has recommended the need for African nations to overcome their dependence on donor countries. A stance that is in line with: Ndilovu-Gatsheni (2013) on Africa's entrapment within some colonial webs and matrices. The position of Amin (2013) that neocolonialism could be managing development assistance is a perception that could be used by recipient governments in clinging onto power when aid uncertainties from donors are not founded on solid grounds. He has further professed that development is not a process that can be left to the whims and caprices of donors. A stance shared by Obeng-Odoom (2013) on the imperative of foreign aid to be essentially fueled by African needs. For instance, there are narratives in the aid literature sustaining that developing countries appreciate qualitative characteristics like happiness more (Arvin \& Lew, 2010ab, 2011, 2012ab).

\footnotetext{
${ }^{7}$ We discuss this in some detail in the paragraph on a new Washington consensus below.
} 


\subsubsection{Implications for underlying debates}

It has been observed from the findings that foreign aid distortions as a policy instrument for the promotion of political rights is a considerable policy reversal because it brings about the opposite effect. This finding contributes to the underlying literature and recent debates in a sixfold manner. First, it is a confirmation of the Moyo conjecture/hypothesis on the short-term inappropriateness of the Washington consensus on the priority of political rights (Moyo, 2013). The short-term inference draws from the fact that GMM estimated coefficients are interpreted as short-term effects, essentially because non-overlapping intervals have been employed to mitigate short-run disturbances that may loom substantially. Second, the Lalountas et al. (2011) conjecture that has been verified in Africa by Asongu (2014a) ${ }^{8}$ is also broadly confirmed. Therefore with globalization, African nations could be more preoccupied by economic rights than political rights. This interpretation is based on an underlying hypothesis that development assistance is an instrument of globalization ('privatize/liberalize and you would receive more aid'). Third, with respect to the Okada \& Samreth (2012) and 'Asongu \& Jellal (2013) and Asongu (2012a, 2013a)' debate on 'the effect of foreign aid on the quality of institutions', the Okada \& Samreth corruption-related results for developing countries may yet be irrelevant for Africa. Fourth, institutions may be more endogenous to productive structures, economic rights or economic prosperity (Asongu \& Aminkeng, 2013; Ortmann, 2012; Anyanwu \& Erhijakpor, 2014). Fifth, partial confirmation of the level and time hypotheses for the rewards of liberal democracy (Scott,

\footnotetext{
${ }^{8}$ Asongu (2014a) has verified the Lalountas et al. (2011, p. 645) hypothesis in Africa: "Thus, our main conclusion is that globalization could be a powerful means of fighting corruption, only for middle and high income countries. For low income countries however, globalization has no significant impact on corruption. We might therefore conclude that at low levels of per capita income emphasis is given to the economic dimension of international integration and as a result the effect of globalization on corruption is limited. Persistence on globalization as an effective means to reduce corruption in developing countries might lead to inappropriate policies. On the contrary, at high levels of per capita income emphasis is given to the political and social dimensions of globalization and as a result the effects of this phenomenon on corruption control are significant" (page 645).
} 
1972; Lemarchand, 1972; Sayari, 1977; Wade, 1985; Weyland, 1998; Varsee, 1997; Montinola \& Jackman, 2002; Back \& Hadenius, 2008; Sung, 2004; Asongu, 2012b; Asongu, 2011). Sixth, more light is thrown into: Eubank (2012) versus Asongu (2014b) and Kongoye (2013) versus Asongu (2014b) literature. Essentially because less reliance on foreign aid by partial democracies could oblige governments to improve governance standards in exchange for more tax revenues from the local population who are only willing to consent to paying more taxes if the government improves its economic and institutional dimensions. Notably: the formulation and implementation of policies that deliver public commodities (economic governance) and the improvement of respect by the state and citizens of institutions that govern interactions between them (institutional governance).

\subsubsection{Implications for a new Washington Consensus}

While donors and past colonial masters are increasingly bargaining for more influence with their money, the task at hand is to request higher standards of governance that are consistent with the demands of the local population. Hence, this would enhance democracy and not be used by populist political parties against aid donors.

In order to fully understand the need for a new Washington consensus, we devote some space to elucidate the recent experience of Uganda. As reported by Aljazeera (February, 2014), in support of the planned freeze or change (uncertainty) of aid programmes in Uganda by Norway, the Netherlands and Denmark, the World Bank promptly froze aid to the country over the antigay law. The reason given for the suspension was that the global lender who wanted to ascertain the US\$90 million loan ensured objectives of development that were not adversely affected by the new law. In response, the Ugandan government was quick to ask the World Bank to keep its aid and that the country could develop without Western assistance. The Ugandan government 
remained confident because it had the support of the people in the passing of the bill. Indeed qualification of the bill by US Secretary of State John Kerry as 'flat-out morally wrong' and 'atrocious' and further comparing it with the standards of apartheid in South Africa or 'antiSemitic legislation in Nazi Germany' did not go down well with the Ugandan government.

We have found from our results that using foreign aid uncertainty to achieve democracy may end-up mitigating the democracy that the volatility was initially aimed at enhancing. Hence, as a principal policy recommendation, donors should carefully consider the stakes before using foreign aid uncertainty as a tool to enhance political rights in recipient countries. They should not stake their reputation on issues that are strongly supported by the electorates, else, they simply give those in power more instruments and incentives with which to consolidate their grip on power.

\section{Conclusions}

Before the collapse of the Berlin wall, the underlying motivations of foreign aid were Cold War strategies. The enhancement of political rights was not an essential item on the development agenda. Developing countries receiving substantial amounts of foreign aid did not improve in political rights or democratic standards because it was not in the interest of donor nations for them to become primarily accountable to their citizens. After the Cold War, the Washington consensus adopted the promotion of political rights as a prime development strategy and used foreign aid to enforce the goal. Hence, a wide consensus that foreign aid as a policy instrument for the promotion of political rights in recipient countries has been made uncertain by donors so as to achieve the objective of enhancing democracy. This study has complemented existing literature on the aid-institutions nexus by focusing on: political rights, aid volatilities and, the post-Berlin Wall period. The findings show that while foreign aid does not have a 
significant effect on political rights, foreign aid volatilities do mitigate democracy in recipient countries. Volatilities could be used by populist parties to promote a neocolonial agenda, instill nationalistic sentiments and consolidate their grip on power. This is especially the case when donors are asking for standards that the majority of the population do not want and political leaders are unwilling to implement. This sends a strong signal on political accountability reversal: governments are constrained to be more accountable to donors instead of the electorate that put them into office. The empirical evidence is based on 53 African countries for the period 19962010. As a main policy implication, using foreign aid uncertainty as an instrument of political rights enhancement in African countries may achieve the opposite results. Other implications are discussed including the need for a new Washington consensus. 
Table 1: Foreign aid uncertainties with standard deviations

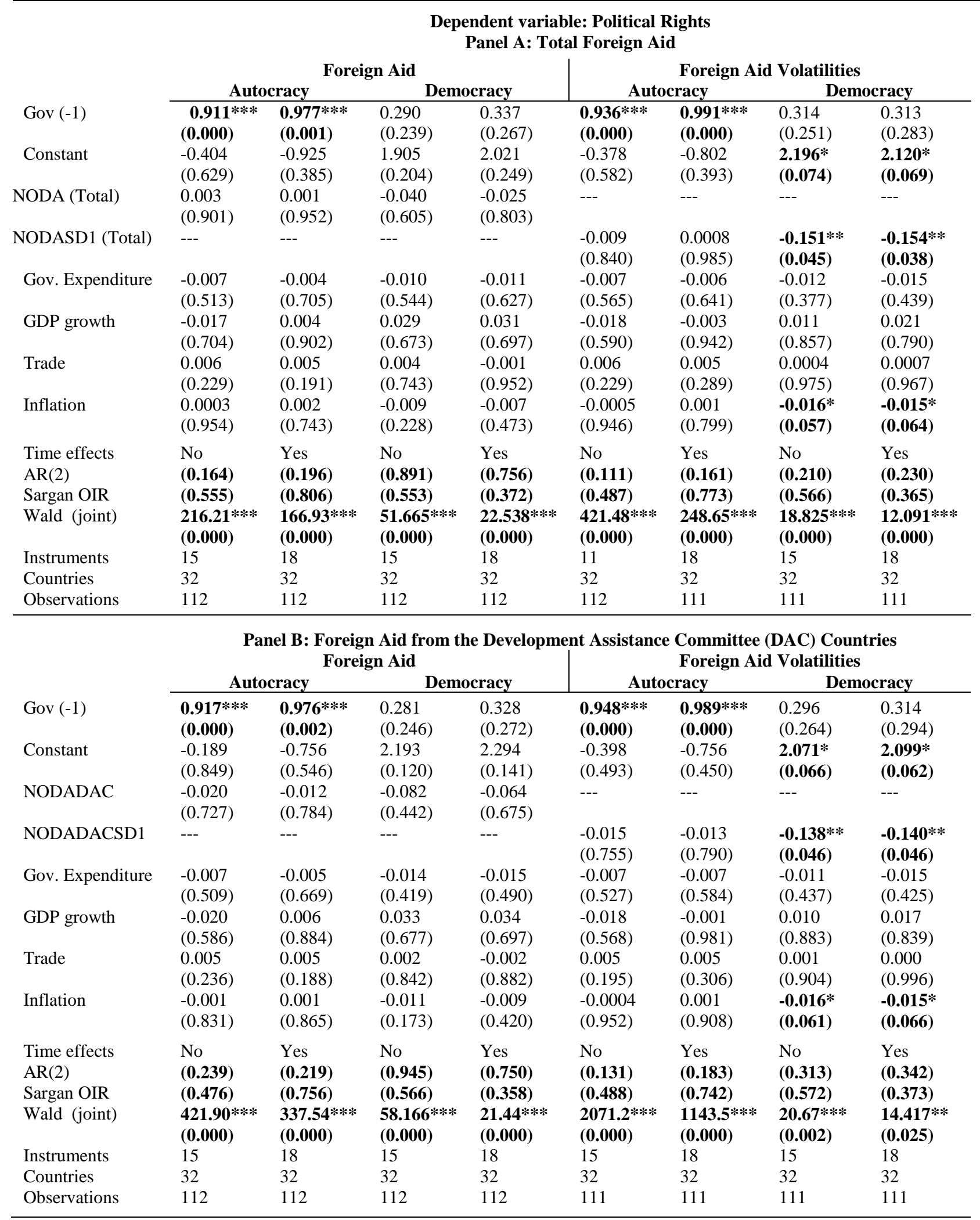

***, **, and * indicate significance at $1 \%, 5 \%$ and $10 \%$ levels respectively. AR(2): Second Order Autocorrelation test. OIR: Overidentifying Restrictions test. The significance of bold values is twofold. 1) The significance of estimated coefficients and the Wald statistics. 2) The failure to reject the null hypotheses of: a) no autocorrelation in the AR(2) tests and; b) the validity of the instruments in the Sargan OIR test. P-values in 
bracket. Gov: Government. NODA: Total Net Official Development Assistance. NODASD1(Total): Volatilities by Simple Standard Deviation of Total NODA. NODADAC: Net Official Development Assistance from the Development Assistance Committee. NODADAC SD1: Volatilities by Simple Standard Deviation from NODADAC.

\section{Table 2: Foreign aid uncertainties with standard errors}

\begin{tabular}{|c|c|c|c|c|c|c|c|c|}
\hline \multirow[b]{4}{*}{ Gov $(-1)$} & \multicolumn{8}{|c|}{$\begin{array}{l}\text { Dependent variable: Political Rights } \\
\text { Panel A: Total Foreign Aid }\end{array}$} \\
\hline & \multicolumn{4}{|c|}{ Foreign Aid } & \multicolumn{4}{|c|}{ Foreign Aid Volatilities } \\
\hline & \multicolumn{2}{|c|}{ Autocracy } & \multicolumn{2}{|c|}{ Democracy } & \multicolumn{2}{|c|}{ Autocracy } & \multicolumn{2}{|c|}{ Democracy } \\
\hline & $\begin{array}{l}0.911 * * * * \\
(0.000)\end{array}$ & $\begin{array}{l}0.977 * * * * \\
(0.001)\end{array}$ & $\begin{array}{l}0.290 \\
(0.239)\end{array}$ & $\begin{array}{l}0.337 \\
(0.267)\end{array}$ & $\begin{array}{l}0.946 * * * * \\
(0.000)\end{array}$ & $\begin{array}{l}0.992 * * * \\
(0.000)\end{array}$ & $\begin{array}{l}0.309 \\
(0.254)\end{array}$ & $\begin{array}{l}0.316 \\
(0.273)\end{array}$ \\
\hline Constant & $\begin{array}{l}-0.404 \\
(0.629)\end{array}$ & $\begin{array}{l}-0.925 \\
(0.385)\end{array}$ & $\begin{array}{l}1.905 \\
(0.204)\end{array}$ & $\begin{array}{l}2.021 \\
(0.249)\end{array}$ & $\begin{array}{l}-0.402 \\
(0.475)\end{array}$ & $\begin{array}{l}-0.796 \\
(0.404)\end{array}$ & $\begin{array}{l}\text { 2.191* } \\
(0.074)\end{array}$ & $\begin{array}{l}2.128 * \\
(0.057)\end{array}$ \\
\hline NODA (Total) & $\begin{array}{l}0.003 \\
(0.901)\end{array}$ & $\begin{array}{l}0.001 \\
(0.952)\end{array}$ & $\begin{array}{l}-0.040 \\
(0.605)\end{array}$ & $\begin{array}{l}-0.025 \\
(0.803)\end{array}$ & --- & --- & --- & --- \\
\hline NODASD2 (Total) & --- & --- & --- & --- & $\begin{array}{l}-0.006 \\
(0.809)\end{array}$ & $\begin{array}{l}-0.002 \\
(0.950)\end{array}$ & $\begin{array}{l}-0.102 * \\
(0.066)\end{array}$ & $\begin{array}{l}-0.105 * * \\
(0.038)\end{array}$ \\
\hline Gov. Expenditure & $\begin{array}{l}-0.007 \\
(0.513)\end{array}$ & $\begin{array}{l}-0.004 \\
(0.705)\end{array}$ & $\begin{array}{l}-0.010 \\
(0.544)\end{array}$ & $\begin{array}{l}-0.011 \\
(0.627)\end{array}$ & $\begin{array}{l}-0.008 \\
(0.481)\end{array}$ & $\begin{array}{l}-0.006 \\
(0.636)\end{array}$ & $\begin{array}{l}-0.010 \\
(0.461)\end{array}$ & $\begin{array}{l}-0.015 \\
(0.474)\end{array}$ \\
\hline GDP growth & $\begin{array}{l}-0.017 \\
(0.704)\end{array}$ & $\begin{array}{l}0.004 \\
(0.902)\end{array}$ & $\begin{array}{l}0.029 \\
(0.673)\end{array}$ & $\begin{array}{l}0.031 \\
(0.697)\end{array}$ & $\begin{array}{l}-0.018 \\
(0.630)\end{array}$ & $\begin{array}{l}-0.002 \\
(0.949)\end{array}$ & $\begin{array}{l}-0.002 \\
(0.976)\end{array}$ & $\begin{array}{l}0.014 \\
(0.866)\end{array}$ \\
\hline Trade & $\begin{array}{l}0.006 \\
(0.229)\end{array}$ & $\begin{array}{l}0.005 \\
(0.191)\end{array}$ & $\begin{array}{l}0.004 \\
(0.743)\end{array}$ & $\begin{array}{l}-0.001 \\
(0.952)\end{array}$ & $\begin{array}{l}0.006 \\
(0.214)\end{array}$ & $\begin{array}{l}0.005 \\
(0.292)\end{array}$ & $\begin{array}{l}0.0008 \\
(0.954)\end{array}$ & $\begin{array}{l}0.0006 \\
(0.973)\end{array}$ \\
\hline Inflation & $\begin{array}{l}0.0003 \\
(0.954)\end{array}$ & $\begin{array}{l}0.002 \\
(0.743)\end{array}$ & $\begin{array}{l}-0.009 \\
(0.228)\end{array}$ & $\begin{array}{l}-0.007 \\
(0.473)\end{array}$ & $\begin{array}{l}0.0001 \\
(0.978)\end{array}$ & $\begin{array}{l}0.001 \\
(0.822)\end{array}$ & $\begin{array}{l}-0.016 * \\
(0.069)\end{array}$ & $\begin{array}{l}-0.016 * \\
(0.058)\end{array}$ \\
\hline $\begin{array}{l}\text { Time effects } \\
\operatorname{AR}(2)\end{array}$ & $\begin{array}{l}\text { No } \\
(\mathbf{0 . 1 6 4 )}\end{array}$ & $\begin{array}{l}\text { Yes } \\
(\mathbf{0 . 1 9 6 )}\end{array}$ & $\begin{array}{l}\text { No } \\
(\mathbf{0 . 8 9 1 )}\end{array}$ & $\begin{array}{l}\text { Yes } \\
(\mathbf{0 . 7 5 6 )}\end{array}$ & $\begin{array}{l}\text { No } \\
(\mathbf{0 . 1 0 3 )}\end{array}$ & $\begin{array}{l}\text { Yes } \\
(\mathbf{0 . 1 4 0 )}\end{array}$ & $\begin{array}{l}\text { No } \\
(\mathbf{0 . 2 9 0 )}\end{array}$ & $\begin{array}{l}\text { Yes } \\
(\mathbf{0 . 2 8 2})\end{array}$ \\
\hline Sargan OIR & $(0.555)$ & $(0.806)$ & $(0.553)$ & $(0.372)$ & $(0.505)$ & $(0.762)$ & $(0.563)$ & $(0.350)$ \\
\hline Wald (joint) & $\begin{array}{l}\text { 216.21**** } \\
(0.000)\end{array}$ & $\begin{array}{l}166.93 * * * * \\
(0.000)\end{array}$ & $\begin{array}{l}\mathbf{5 1 . 6 6 5} * * * * \\
(\mathbf{0 . 0 0 0 )}\end{array}$ & $\begin{array}{l}\text { 22.538**** } \\
(0.000)\end{array}$ & $\begin{array}{l}\text { 403.54**** } \\
(0.000)\end{array}$ & $\begin{array}{l}\text { 321.24**** } \\
(\mathbf{0 . 0 0 0 )}\end{array}$ & $\begin{array}{l}14.920 * * \\
(0.020)\end{array}$ & $\begin{array}{l}14.242 * * \\
(0.027)\end{array}$ \\
\hline Instruments & 15 & 18 & 15 & 18 & 15 & 18 & 15 & 18 \\
\hline Countries & 32 & 32 & 32 & 32 & 32 & 32 & 32 & 32 \\
\hline Observations & 112 & 112 & 112 & 112 & 111 & 111 & 111 & 111 \\
\hline
\end{tabular}

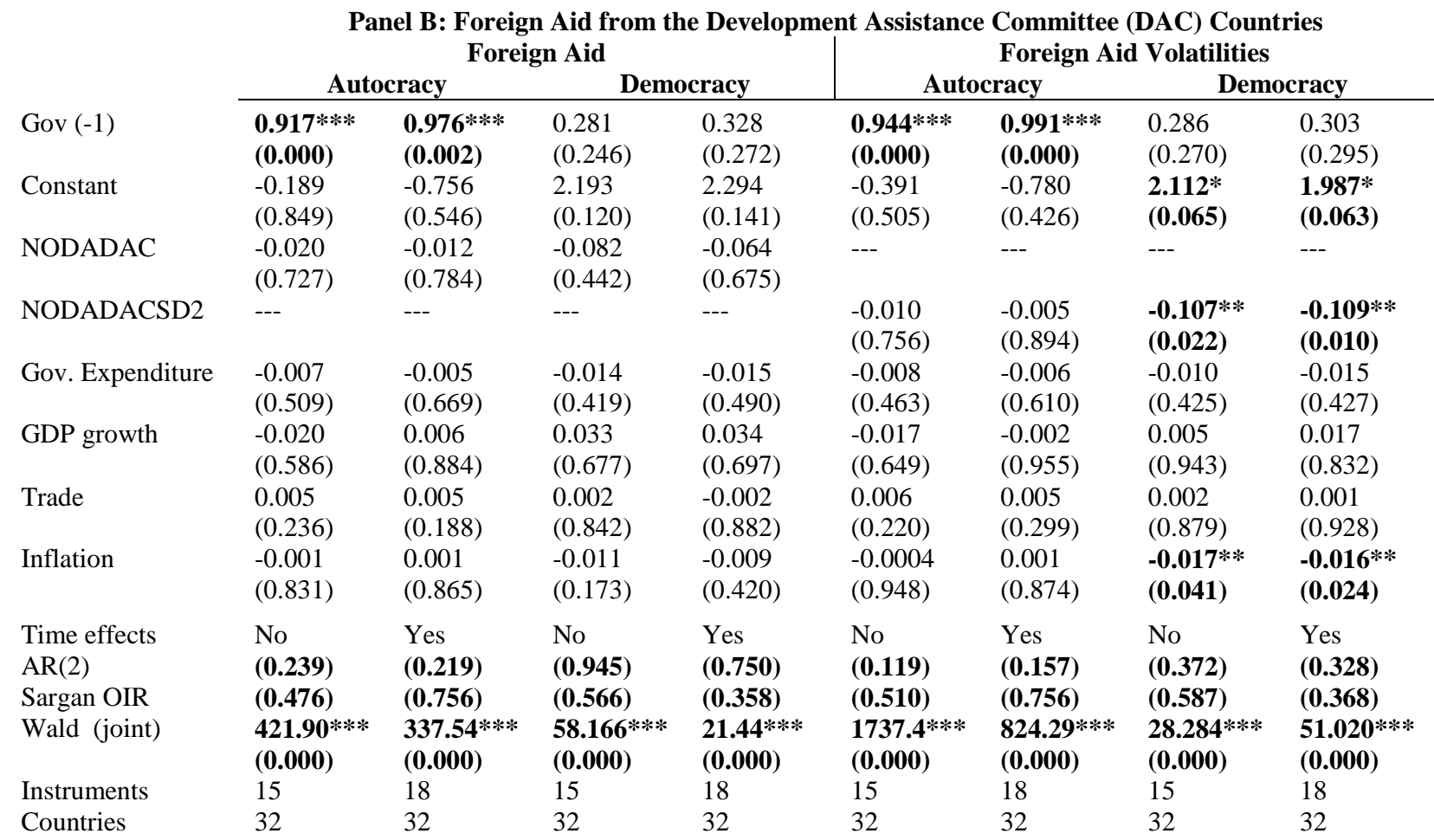


***,**, and * indicate significance at 1\%,5\% and 10\% levels respectively. AR(2): Second Order Autocorrelation test. OIR: Overidentifying Restrictions test. The significance of bold values is twofold. 1) The significance of estimated coefficients and the Wald statistics. 2) The failure to reject the null hypotheses of: a) no autocorrelation in the AR(2) tests and; b) the validity of the instruments in the Sargan OIR test. P-values in bracket. Gov: Government. NODA: Total Net Official Development Assistance. NODASD1(Total): Volatilities by Standard Errors of Total NODA. NODADAC: Net Official Development Assistance from the Development Assistance Committee..NODADAC SD1: Volatilities by Standard Errors from NODADAC.

\section{Appendices}

\section{Appendix 1: Definitions of variables}

\begin{tabular}{|c|c|c|}
\hline Variable(s) & Definition(s) & Source(s) \\
\hline NODA (Total) & $\begin{array}{l}\text { Total Net Official Development Assistance (NODA) (\% of } \\
\text { GDP) }\end{array}$ & World Bank (WDI) \\
\hline NODADAC & $\begin{array}{l}\text { NODA from the Development Assistance Committee Countries } \\
\text { ( } \% \text { of GDP) }\end{array}$ & World Bank (WDI) \\
\hline NODASD1 (Total) & Distortions of Total NODA by Simple Standard Deviation & Author \\
\hline NODADACSD1 & Distortions of NODADAC by Simple Standard Deviation. & Author \\
\hline NODASD2 (Total) & $\begin{array}{l}\text { Distortions of Total NODA by Standard Deviation of the } \\
\text { Residuals after first-order autoregressive process. }\end{array}$ & Author \\
\hline NODADACSD2 & $\begin{array}{l}\text { Distortions of NODADAC by Standard Deviation of the } \\
\text { Residuals after first-order autoregressive process. }\end{array}$ & Author \\
\hline Democracy & $\begin{array}{l}\text { Institutionalized democracy. Democracy is conceived as three } \\
\text { essential, interdependent elements. One is the presence of } \\
\text { institutions and procedures through which citizens can express } \\
\text { effective preferences about alternative policies and leaders. } \\
\text { Second is the existence of institutionalized constraints on the } \\
\text { exercise of power by the executive. Third is the guarantee of } \\
\text { civil liberties to all citizens in their daily lives and in acts of } \\
\text { political participation. Other aspects of plural democracy, such } \\
\text { as the rule of law, systems of checks and balances, freedom of } \\
\text { the press, and so on are means to, or specific manifestations of, } \\
\text { these general principles. }\end{array}$ & World Bank (WDI) \\
\hline Autocracy & $\begin{array}{l}\text { Institutionalized autocracy. The opposite definition of } \\
\text { Institutionalized democracy above. }\end{array}$ & World Bank (WDI) \\
\hline GDP growth & Gross Domestic Product growth rate (annual \%) & World Bank (WDI) \\
\hline $\begin{array}{l}\text { Trade Openness } \\
\text { Government Expenditure }\end{array}$ & $\begin{array}{l}\text { Exports plus Imports of Commodities ( } \% \text { of GDP) } \\
\text { Government Final Consumption Expenditure( } \% \text { of GDP) }\end{array}$ & $\begin{array}{l}\text { World Bank (WDI) } \\
\text { World Bank (WDI) }\end{array}$ \\
\hline Inflation & Consumer Price Index (annual \%) & World Bank (WDI) \\
\hline
\end{tabular}

WDI: World Bank Development Indicators. GDP: Gross Domestic Product. PCA: Principal Component Analysis. NODA: Net Official Development Assistance. NODADAC: NODA from the Development Assistance Committee (DAC) countries. NODAMD: NODA from Multilateral Donors. SD1: Distortions by Simple Standard Deviation. SD2: Distortions by Standard Deviation of the Residuals after first-order autoregressive processes. 
Appendix 2: Summary statistics

Total NODA

NODADAC

First Distortions from Total NODA

First Distortions from Total NODADAC

Second Distortions from Total NODA

Second Distortions from Total NODADAC

Autocracy

Democracy

GDP growth

Trade Openness

Government Expenditure

Inflation

\begin{tabular}{ccccc} 
Mean & S.D & Min & Max & Obs. \\
\hline 10.889 & 12.029 & 0.015 & 102.97 & 253 \\
6.278 & 7.303 & -0.003 & 68.063 & 253 \\
2.841 & 6.460 & 0.001 & 64.113 & 250 \\
1.868 & 4.790 & 0.0005 & 44.404 & 250 \\
3.409 & 8.106 & 0.005 & 91.927 & 250 \\
2.201 & 6.333 & 0.001 & 68.826 & 250 \\
1.905 & 3.401 & -8.000 & 9.000 & 250 \\
2.373 & 3.871 & -8.000 & 10.000 & 250 \\
4.755 & 5.587 & -11.272 & 49.367 & 254 \\
78.340 & 39.979 & 20.980 & 250.95 & 247 \\
4.495 & 8.064 & -17.387 & 49.275 & 164 \\
56.191 & 575.70 & -45.335 & 8603.3 & 230
\end{tabular}

S.D: Standard Deviation. Min: Minimum. Max: Maximum. Obs: Observations. NODA: Net Official Development Assistance. DAC: Development Assistance Committee. SD1: Distortions by Simple Standard Deviation. SD2: Distortions by Standard Deviation of the Residuals after first-order autoregressive processes. 
Appendix 3: Correlation Analysis

\begin{tabular}{|c|c|c|c|c|c|c|c|c|c|c|c|c|}
\hline \multicolumn{2}{|c|}{ Foreign Aid } & \multicolumn{4}{|c|}{ Foreign Aid Uncertainty } & \multirow[b]{2}{*}{ GDPg } & \multicolumn{2}{|c|}{ Control Variables } & \multicolumn{4}{|c|}{ Political Rights } \\
\hline Aid1 & Aid2 & Aid1SD1 & Aid2SD1 & Aid1SD2 & Aid2SD2 & & Trade & Gov. Exp & Inflation & Autocracy & Democracy & \\
\hline & 1.000 & 0.805 & 0.756 & 0.809 & 0.767 & 0.109 & -0.061 & 0.077 & -0.011 & -0.276 & -0.015 & Aid2 \\
\hline & & & 1.000 & 0.901 & 0.946 & 0.193 & 0.050 & 0.024 & 0.011 & -0.245 & -0.141 & Aid2SD1 \\
\hline & & & & 1.000 & 0.945 & 0.145 & 0.101 & 0.028 & -0.003 & -0.213 & -0.078 & Aid1SD2 \\
\hline & & & & & 1.000 & 0.091 & 0.091 & 0.028 & -0.0006 & -0.217 & -0.088 & Aid2SD2 \\
\hline & & & & & & 1.000 & 0.179 & 0.254 & -0.132 & 0.098 & 0.014 & GDPg \\
\hline & & & & & & & & & 1.000 & 0.041 & -0.058 & Inflation \\
\hline & & & & & & & & & & 1.000 & 0.020 & Autocracy \\
\hline & & & & & & & & & & & 1.000 & Democracy \\
\hline
\end{tabular}

Aid1: Total Net Official Development Assistance (NODA). Aid2: NODA from the Development Assistance Committee (DAC) Countries (NODADAC). Aid1SD1: NODA Distortions by Simple Standard Deviations. Aid2SD1: NODADAC Distortions by Simple Standard Deviations. Aid1SD2: NODA Distortions by Simple Standard Errors. Aid2SD2:

NODADAC Distortions by Simple Standard Errors. GDPg: Gross Domestic Product growth. Trade: Trade Openness. Gov. Exp: Government Expenditure. 


\section{References}

Akomolafe, F., (2008). "No one is laughing at the Asians anymore: Femi Akomolafe on the lessons Africa can learn from China: Stop listening to the West and your economic dreams will come true", New Africa.

Alesina, A., \& Dollar, D. (2000). "Who gives Foreign Aid to Whom and Why?" Journal of Economic Growth, 5(1), pp. 33-64.

Alesina, A., \& Weder, B. (2002). "Do Corrupt Governments Receive Less Foreign Aid?" American Economic Review 92(4), pp. 1126-1137.

Aljazeera (2014, February). "World Bank freezes aid to Uganda over gay law", Aljazeera English, http://www.aljazeera.com/news/africa/2014/02/world-bank-freezes-aid-uganda-overgay-law-201422874410793972.html (Accessed: 11/06/2014).

Amavilah, V. H., (1998). "German aid and trade versus Namibian GDP and labour productivity", Applied Economics, 30(5), pp. 689-695.

Amin, S., (2014). “Aid for Development", Springer Briefs on Pioneers in Science and Practice, 16(2014), pp. 125-137.

Anyanwu, J. C., \& Erhijakpor, A. E. O., (2014). "Does Oil Wealth Affect Democracy in Africa?", African Development Review, 26 (1), pp. 15-37.

Arellano, M., \& Bond, S. (1991). "Some tests of specification for panel data: Monte Carlo evidence and an application to employment equations" The Review of Economic Studies 58(2), pp. 277-297.

Arellano, M., \& Bover, O. (1995). "Another look at the instrumental variable estimation of errorcomponents models" Journal of Econometrics 68(1), pp. 29-52.

Armah, S., \& Carl, N. H., (2008). "Is Foreign Aid Beneficial for Sub-Saharan Africa? A Panel Data Analysis", Agricultural and Applied Economics Association, 2008 Annual Meeting, July 27-29.

Arvin, B. M., \& Lew, B., (2010a). "Aid and happiness: untangling the causal relationship in nine European donor countries", Global Business and Economic Review, 12(4), pp. 341-358.

Arvin, B. M., \& Lew, B., (2010b). "Does Happiness Affect the Bilateral Aid Flows Between Donor and Recipient Countries?", The European Journal of Development Research, 22(4), pp. 546-563. 
Arvin, B. M., \& Lew, B., (2011). "Are foreign aid and migrant remittances sources of happiness in recipient countries", International Journal of Public Policy, 7(4/5/6), pp. 282-300.

Arvin, B. M., \& Lew, B., (2012a). "Do happiness and foreign aid affect bilateral migrant remittances?", Journal of Economic Studies, 39(2), pp. 212-230.

Arvin, B. M., \& Lew, B., (2012b). "Development Aid, Corruption and the Happiness of Nations: Analysis of 118 countries over the years 1996-2009”, Applied Econometrics and International Development, 12(2), pp. 69-78.

Asongu, S. A. (2011). "Law, democracy and the quality of government in Africa", African Governance and Development Institute Working Paper No. 11/018, Yaoundé.

Asongu, S. A. (2012a). "On the effect of foreign aid on corruption", Economics Bulletin 32(3), pp. 2174-2180.

Asongu, S. A. (2012b). "Government quality determinants of stock market performance in African countries", Journal of African Business, 13(2), pp. 183-199.

Asongu, S. A. (2013a) "On the effectiveness of foreign aid in institutional quality" European Economics Letters 2(1), 12-19.

Asongu, S. A. (2013b). "Harmonizing IPRs on Software Piracy: Empirics of Trajectories in Africa", Journal of Business Ethics, 118(1), pp. 45-60.

Asongu, S. A., (2014a). "Globalization (fighting) corruption and development: how are these phenomena linearly and nonlinearly related in wealth effects", Journal of Economic Studies, 41(3), pp. 346-369.

Asongu, S. A., (2014b). "On foreign aid distortions to governance", African Governance and Development Institute Working Paper No. 14/003, Yaoundé.

Asongu, S. A., (2015). "On taxation, political accountability and foreign aid: empirics to a celebrated literature", South African Journal of Economics, 83(2), pp. 180-198.

Asongu, S. A., \& Aminkeng, G. A. A., (2013). "The economic consequences of China-Africa relations: debunking myths in the debate", Journal of Chinese Economic and Business Studies, 11(4), pp. 261-277.

Asongu, S. A., \& Jellal, M. (2013). "On the channels of foreign aid to corruption", Economics Bulletin, 33(3), pp. 2191-2201.

Babatunde, M. A., (2012). "Africa's Growth and Development Strategies: A Critical Review", African Development, Africa Development, XXXVII, (4), pp. 141-178.

Back, H., \& Hadenius, A., (2008). "Democracy and State Capacity: Exploring a J-Shaped Relationship.”, Governance, 21 (1),pp. 1-24. 
Baliamoune-Lutz, M., (2013). “Tunisia's Development Experience: A Success Story?", In Achieving Development Success: Strategies and Lessons from the Developing World, ed. Fosu, A., Oxford University Press, pp. 457-480.

Banuri, T.. (2013). "Sustainable Development is the New Economic Paradigm", Development, 56(2), pp. 208-217.

Blundell, R., \& Bond, S. (1998). "Initial conditions and moment restrictions in dynamic panel data models" Journal of Econometrics, 87(1), pp. 115-143.

Bond, S., Hoeffler, A., \& Tample, J. (2001). "GMM Estimation of Empirical Growth Models", University of Oxford.

Brown, S., (2005). "Foreign aid and democracy promotion: lessons from Africa", The European Journal of Development Research, 17(2), pp. 172-198.

Cardoso, E., (2013). "Between Past and Future of Latin America: Lessons from Brazil, Chile, Costa Rica and the Dominican Republic ", In Achieving Development Success: Strategies and Lessons from the Developing World, ed. Fosu, A., Oxford University Press, pp. 406-415.

Carmody, P., \& Owusu, F., (2007). "Chinese vs. America geoeconomic strategies in Africa", Political Geography, Political Geography, 26(5), pp. 504-524.

Carothers, T., (2000). “Aiding democracy abroad: the learning curve”, Carnegie Endowment for International Peace, Massachusetts, Washington D.C.

Collier, P. (2007). The Bottom Billion: Why the Poorest Countries Are Failing and What Can Be Done About It ?, Oxford University Press.

Crawford, G., (2001). Foreign aid and political reform: a comparative analysis of democracy assistance and political conditionality (Ed. Crawford) in International Political Economy Series.

Clinton, H. R., (2011, June). "Interview on Africa 360", U.S Department of State, Diplomacy in Action. http://www.state.gov/secretary/rm/2011/06/165941.htm (Accessed: 16/08/2012)

De Mello, L., (2013). "Brazil's Growth Performance: Achievements and Prospects", In Achieving Development Success: Strategies and Lessons from the Developing World, ed. Fosu, A., Oxford University Press, pp. 295-320.

Dixit, A. (2004). Lawlessness and Economics: Alternative Modes of Governance. Princeton: University Press.

Djankow, S., Montalvo, J. G., \& Reynal-Querol, M., (2008). "The Curse of Aid", Journal of Economic Growth, 13(3), pp. 169-194. 
Drine, I., (2013). "'Successful' Development Models: Lessons from the MENA Region”, In Achieving Development Success: Strategies and Lessons from the Developing World, ed. Fosu, A., Oxford University Press, pp. 496-504.

Easterly, W. (2005). “Can foreign aid save Africa”, Saint John’s University.

Elagati, M., (2013). "Foreign funding in Egypt after the revolution", FRIDE, A European Think Tank for Global Action: http://www.fride.org/download/WP_EGYPT.pdf (Accessed: 11/06/2014).

Eubank, N. (2012). "Taxation, Political Accountability and Foreign Aid: Lessons from Somaliland", Journal of Development Studies, 48(4), pp. 465-480.

Faust, J., (2010). "Policy Experiments, Democratic Ownership and Development Assistance", Development Policy Review, 28(5), pp. 515-534.

Fosu, A., (2010), “Africa's Economic Future: Learning from the Past", CESifo Forum, Info Institute for Economic Research at the University of Munich, 11(1), pp. 62-71.

Fosu, A., (2012), "Development Success: Historical Accounts from More Advanced Countries", UNU-WIDER Research Paper.

Fosu, A., (2013a), "Achieving development success: Strategies and lessons from the developing world”, UNU-WIDER Policy Brief (November).

Fosu, A., (2013b). "Country Role Models for Development Success: The Ghana Case", In Achieving Development Success: Strategies and Lessons from the Developing World, ed. Fosu, A., Oxford University Press, pp. 265-283.

Ghosh, J. (2013). “Towards a Policy Framework for Reducing Inequalities”, Development, 56(2), pp. 218-222.

Gibson, C., Hoffman, B., \& Jablonski, R., (2014). "Did Aid Promote Democracy in Africa? The Role of Technical Assistance in Africa's Transitions”, University of California, San Diego. http://ryanjablonski.files.wordpress.com/2014/05/did-aid-promote-democracy-in-africa.pdf (Accessed: 05/06/2014).

Hayman, R., (2011). "Budget Support and Democracy: a twist in the conditionality tale", Third World Quarterly, 32(4), pp. 673-688.

Hopkins, R. F., (2000), Political Economy of Foreign Aid, in: Tarp, F. (ed.) Foreign Aid and Development: Lessons Learnt and Directions for the Future, London: Routledge, pp. 423449.

Jellal, M., \& Bouzahzah, M., (2012). "Corruption and tax evasion: an optimal policy", MPRA Paper No. 38813, Munich. 
Jensen, N., \& Wantchekon, L., (2004). "Resource wealth and political regimes in Africa. Comparative Political Studies", 37(7), pp. 816-841.

Jomo, K. S., \& Wee, C. H., (2013). "Lessons from Post-Colonial Malaysian Economic Development", In Achieving Development Success: Strategies and Lessons from the Developing World, ed. Fosu, A., Oxford University Press, pp. 50-71.

Kalyvitis, S., \& Vlachaki, I., (2008). "Democratic aid and the democratization of recipients", Department of International and European Economic Studies, Athens University of Economics and Business.

Kangoye, T., (2011). "Does foreign aid promote democracy?", UNU-WIDER Working Paper 2011/64, Helsinki.

Kangoye, T., (2013). "Does Aid Unpredictability Weaken Governance? Evidence From Developing Countries", The Developing Economies, 51(2), pp. 121-144.

Kano, D. Y., \& Montinola, G. R., (2009). "Does Foreign Aid Support Autocrats, Democrats, or Both?”, The Journal of Politics, 71(2), pp. 704-718.

Killick, T., (2003). "Aid and the political economy of policy change”, Taylor and Francis.

Kindiki, M. M., (2011), "International Regime Governance and Apparel Labour Upgrading in Export Processing Zones in Urban Kenya”, African Review of Economics and Finance, 3(1), pp. 26-40.

Khan, H. A., (2013). "Development Strategies: Lessons from the Experiences of South Korea, Malaysia, Thailand and Vietnam", In Achieving Development Success: Strategies and Lessons from the Developing World, ed. Fosu, A., Oxford University Press, pp. 119-130.

Knack, S. (2001). “Aid Dependence and the Quality of Governance: Cross-Country Empirical Tests", Southern Economic Journal 68(2), pp. 310-329.

Knack, S., (2004). "Does foreign aid promote democracy?", International Studies Quarterly, 48(1), pp. 251-266.

Krause, U. (2013). "Innovation: The new Big Push or the Post-Development alternative?", Development, 56(2), pp. 223-226.

Lalountas, D.A., Manolas, G.A., \& Vavouras, I.S., (2011), "Corruption, globalization and development: How are these three phenomena related?", Journal of Policy Modeling, 33(4), pp.636-648.

Lancaster, C., (1999), Foreign Aid and Development in Africa, Chicago: University of Chicago Press. 
Lee, K., (2013), "How can Korea be a Role Model for Catch-up Development? A 'Capabilitybased' View", In Achieving Development Success: Strategies and Lessons from the Developing World, ed. Fosu, A., Oxford University Press, pp. 25-49.

Lemarchand, R., (1972). "Political Clientelism and Ethnicity in Tropical Africa: Competing Solidarities in Nation-Building," American Political Science Review, 66(1), pp. 68-85.

Looney, R. E., (2013). "The Omani and the Bahraini Paths to Development: Rare and Contrasting Oil-Based Economic Success Stories", In Achieving Development Success: Strategies and Lessons from the Developing World, ed. Fosu, A., Oxford University Press, pp. 419-456.

Lundahl, M., \& Petersson. L., (2013). "Post Apartheid South Africa: An Economic Story?", In Achieving Development Success: Strategies and Lessons from the Developing World, ed. Fosu, A., Oxford University Press, pp. 232-262.

Marangos, J., (2009). "The Evolution of the Term 'Washington Consensus', Journal of Economic Surveys, 23(2), pp. 350-384.

Marglin, S. A. (2013). "Premises for a New Economy”, Development, 56(2), pp. 149-154.

Montinola, G. R., \& Jackman, R.W. (2002). "Sources of Corruption: A Cross-Country Study." British Journal of Political Science, 32, pp.147-170.

Monni, S., \& Spaventa, A., (2013), "Beyond GDP and HDI: Shifting the focus from paradigms to politics", Development, 56(2), pp. 227-231.

Moyo, D. (2009). Dead Aid: Why Aid Is Not Working and How There is Another Way for Africa. New York: Farrar, Straus and Giroux.

Moyo, D., (2013). "Is China a new idol for developing countries", TED Talks, New Ideas Every day, https://www.youtube.com/watch?v=4Q2aznfmcYU (Accessed: 07/05/2014).

Ndlovu-Gatsheni, S. J. (2013). "The Entrapment of African within the Global Colonial Matrices of Power: Eurocentrism, Coloniality and Deimperialieation in the Twenty-first century", Journal of Developing Societies, 29(4), pp. 331-353.

Naudé, W., (2013). "Development Progress in Sub-Saharan Africa: Lessons from Botswana, Ghana, Mauritius and South Africa", In Achieving Development Success: Strategies and Lessons from the Developing World, ed. Fosu, A., Oxford University Press, pp. 284-292.

Nyarko, Y., (2013a). "Sustaining High Economic Growth in Sub-Saharan Africa: Knowledge and the Structure of the Economy", Journal of African Economies, 22, suppl_1(January), pp: -i101.

Nyarko, Y., (2013b). “The United Arab Emirates: Some Lessons in Economic Development”, In Achieving Development Success: Strategies and Lessons from the Developing World, ed. Fosu, A., Oxford University Press, pp. 481-495. 
Obeng-Odoom, F. (2013). "Africa's Failed Economic Development Trajectory: A Critique", African Review of Economics and Finance, 4(2), pp. 151-175.

Okada, K., \& Samreth, S. (2012). "The effect of foreign aid on corruption: A quantile regression approach" Economic Letters 115(2), pp. 240-243.

Ortmann, S., (2012). "The 'Beijing consensus' and the 'Singapore model': unmasking the myth of an alternative authoritarian state-capitalist model", Journal of Chinese Economic and Business Studies, 10(4), pp. 337-359.

Pozo, S., Sanchez-Fung, J., \& Santos-Paulino, A. U., (2013). "Economic Development Strategies in the Dominican Republic", In Achieving Development Success: Strategies and Lessons from the Developing World, ed. Fosu, A., Oxford University Press, pp. 383-405.

Robinson, J., (2013). "Botswana as a Role Model for Country Success", In Achieving Development Success: Strategies and Lessons from the Developing World, ed. Fosu, A., Oxford University Press, pp. 187-203.

Santos-Paulino, A. U., (2013). "Country Role Model of Development Success: Lessons from China and India ", In Achieving Development Success: Strategies and Lessons from the Developing World, ed. Fosu, A., Oxford University Press, pp. 176-184.

Sayari, S., (1977). "Political Patronage in Turkey", in E. Gellner and J. Waterbury (eds.), Patonsand Clients in Mediterranean Societies, London: Duckworth, pp. 103-113.

Schraeder, P. J., Hook, S.W., \& Taylor, B., (1998), 'Clarifying the Foreign Aid Puzzle: A Comparison of American, Japanese, French and Swedish Flows', World Politics 50(2), pp. 294323.

Scott, J. C., (1972). Comparative Political Corruption, Englewood Cliffs, NJ: Prentice-Hall.

Singh, N., (2013). "Democracy, Diversity and Development: India's Strategy and Outcomes", In Achieving Development Success: Strategies and Lessons from the Developing World, ed. Fosu, A., Oxford University Press, pp. 133-175.

Solimano, A., (2013). "Three Decades of Neoliberal Economics in Chile: Achievements, Failures and Dilemmas", In Achieving Development Success: Strategies and Lessons from the Developing World, ed. Fosu, A., Oxford University Press, pp. 321-359.

Stokke, O., (2013). Aid and Political Conditionality, (Ed. Stokke) in EADI Book Series Volume 16, European Association of Development Research and Training Institutes. (First published in 1995).

Subramanian, A., (2013). "The Mauritian Success Story and Its Lessons", In Achieving Development Success: Strategies and Lessons from the Developing World, ed. Fosu, A., Oxford University Press, pp. 204-231. 
Sung, H.E., (2004). "Democracy and political corruption: a cross-national comparison." Crime, Law and Social Change, 41(2), pp.179-194.

Titumir, R. A. M., \& Kamal, M. (2013). "Growing Together Sustainably: A zero-poverty post 2015 development framework”, Development, 56(2), pp. 172-184.

Thoburn, J., (2013). "Vietnam as a Role Model for Development", In Achieving Development Success: Strategies and Lessons from the Developing World, ed. Fosu, A., Oxford University Press, pp. 99-118.

Trejos, A., (2013). "Country Role Models for Development Success: The Case of Costa Rica", In Achieving Development Success: Strategies and Lessons from the Developing World, ed. Fosu, A., Oxford University Press, pp. 360-382.

Tull, D. M., (2006). "China's engagement in Africa: scope, significance and consequences”, The Journal of Modern African Studies, 44(3), pp. 459-479.

Varese, F., (1997). "The Transition to the Market and Corruption in Post-socialist Russia", Political Studies, 45(3), pp. 579-96.

Vicente, P. C., \& Wantchekon, L., (2009). "Clientelism and vote buying; lessons from field experiments in African elections", Oxford Review of Economic Policy, 25(2), pp. 292-305.

Wa Gĩthĩnji, M., \& Adesida, O., (2011). "Industrialization, Exports and the Developmental State in Africa: The Case for Transformation", University of Massachusetts Amberst, Department of Economics Working Paper, No. 2011-18.

Wade, R., (1985). "The Market for Public Office: Why the Indian State is not better at Development.", World Development, 13(4), pp. 467-497.

Wamboye, E., Adekola, A., \& Sergi, B. S. (2013). "Economic Growth and the Role of Foreign Aid in Selected African Countries", Development, 56(2), pp. 155-171.

Wang, L., \& Zheng, J., (2012). "China's rise as a new paradigm in the world economy: preliminaries", Journal of Chinese Economic and Business Studies, 10(4), pp. 301-312.

Wantchekon, L., (2003). "Clientelism and voting behavior: Evidence from a field experiment in Benin”, World Politics, 55(3), pp. 399-422.

Warr, P., (2013). "Thailand's Development Strategy and Growth Performance", In Achieving Development Success: Strategies and Lessons from the Developing World, ed. Fosu, A., Oxford University Press, pp. 72-94.

Weyland, K., (1998). “The Politics of Corruption in Latin America”. Journal of Democracy, 9 (2), pp.108-121. 
Yao, Y. E., (2013). “The Disinterested Government: An Interpretation of China's Economic Success in the Reform Era ", In Achieving Development Success: Strategies and Lessons from the Developing World, ed. Fosu, A., Oxford University Press. 